\title{
Static hardness testing of porous building materials
}

KATALIN SZILÁGYI - BME Department of Construction Materials and Engineering Geology - szilagyikt@gmail.com

ADORJÁN BOROSNYÓI - BME Department of Construction Materials and Engineering Geology - adorjan.borosnyoi@gmail.com

ZoLTÁN GYURKÓ - BME Department of Construction Materials and Engineering Geology

- zoligyurko@gmail.com

Received: 05. 05. 2013. " Érkezett: 2013. 05. 05. " http://dx.doi.org/10.14382/epitoanyag-jsbcm.2013.2

\section{Abstract}

Hardness testing is considered to be the earliest method of material testing. For the measurement of hardness of stones and other porous solid materials mostly dynamic testing devices are applied in practice, however for scientific purposes indentation hardness tests are more suitable methods. In present research Brinell macro hardness tests and depth-sensing indentation (DSI) tests (aka. instrumented indentation tests, IIT) were performed on 15 different types of porous solid building materials, recording the complete loading-unloading responses. The studies have shown that earlier observations found in the literature for the Brinell hardness of concrete can be extended to all porous solid building materials.

Keywords: Brinell hardness, depth-sensing indentation test, strength, Young's modulus, porous solids

\section{Introduction}

In the technical literature limited number of results can be found for porous solid building materials by the Brinell method or the depth-sensing indentation method and most of the studies applied only one or two load levels trying to find a relationship between the Brinell hardness and the compressive strength of concrete. Own earlier studies [1] demonstrated that the power in the Meyer relationship [2] is apparently constant for concrete, independently of the water-cement ratio and the age at testing, while the multiplier in the Meyer relationship is very sensitive to both influencing factors. The results disproved the hypothesis of the power function relationship between the residual indentation diameter and the compressive strength of concrete with a power of -4.0 published earlier in the technical

$\mathrm{HB}, \mathrm{N} / \mathrm{mm}^{2}$

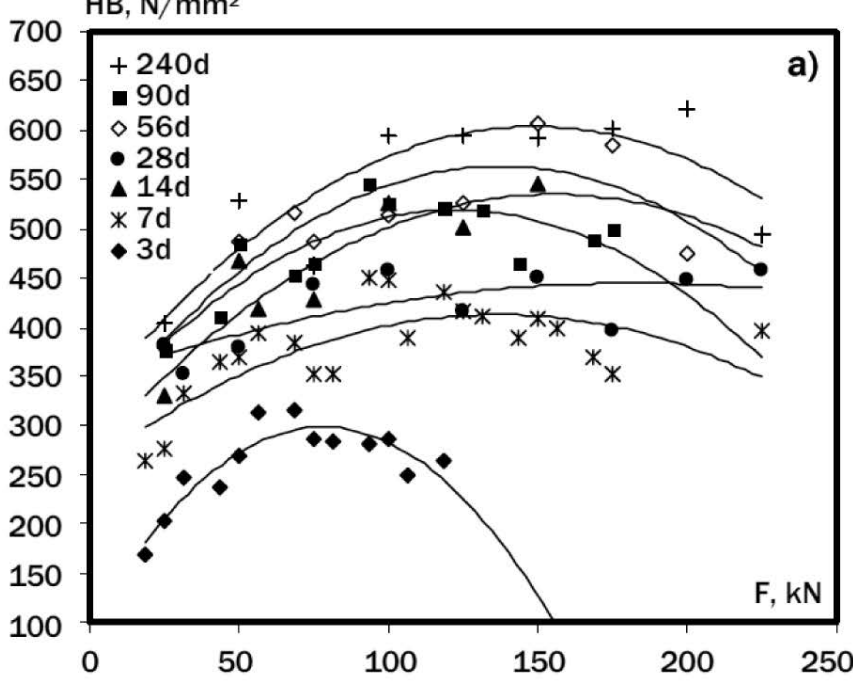

literature. The results confirmed the existence of a linear general model for the relationship between the compressive strength and the Brinell hardness of concrete [3]. During the experiments a special observation was made that clearly illustrates the elastic-plastic behaviour of concrete under the ball indenter as well as the mechanism of local densification and the formation of cone cracking. It was found that Brinell hardness results show an apparent peak value represented as a function of the testing load (Fig. 1.a). If the hardness values are represented as a function of the residual indentation diameter then the same increasing-decreasing tendencies are resulted (Fig. 1.b). Main aim of present experiments was to analyze if the earlier findings for concrete can be extended to further porous solid building materials as well as to study the static hardness behaviour by depth-sensing indentation tests.

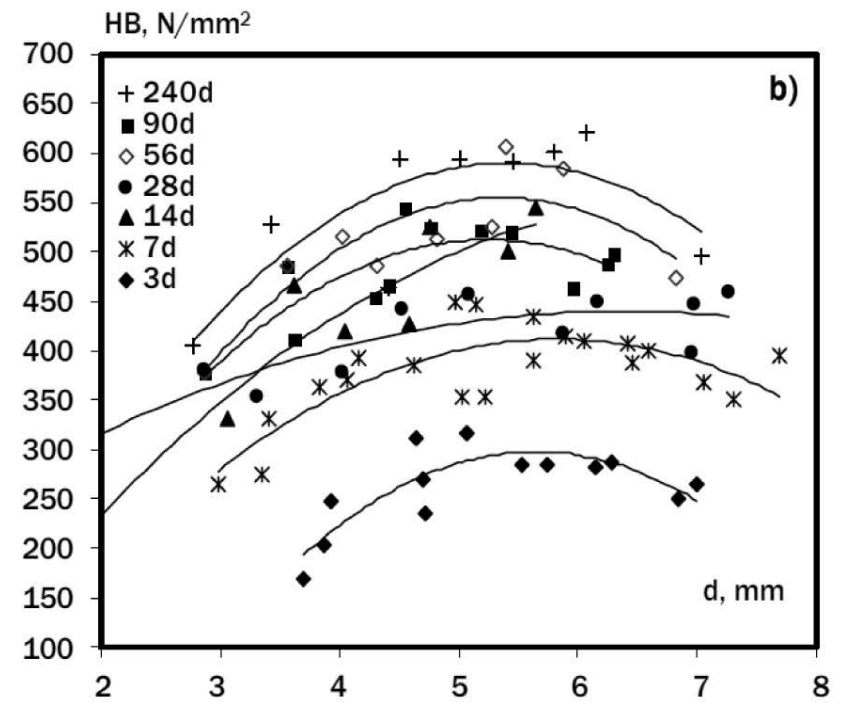

Fig. 1. The relationship of the Brinell hardness, the load and the indentation diameter 1. ábra A Brinell keménység, a terhelöerö és a benyomódási átmérö kapcsolata 


\section{Hardness testing with depth sensing indentation tests}

The depth sensing indentation (DSI) test (aka. instrumented indentation test, IIT) is a widely used indentation test to determine the mechanical properties of materials. The DSI test has two phases (Fig. 2). During the loading period, the indenter body penetrates into the surface of the sample at a constant rate until reaching the maximum value of the load. During the unloading period, the indenter body moves away from the sample with the same rate. Elastic deformation of the material occurs during unloading and displacements are formed in the opposite direction than formed during loading. It is theoretically possible to find the elastic properties, including the Young's modulus, of materials from the unloading curve of the indentation characteristics [4]. In the literature only a few suggestions can be found for the calculation of the Young's modulus based on indentation hardness and most of them applies the Boussinesq problem expressed by Sneddon [5]. Sneddon defined the load vs. indentation depth functions for a linear elastic half-space for various types of indenter bodies.

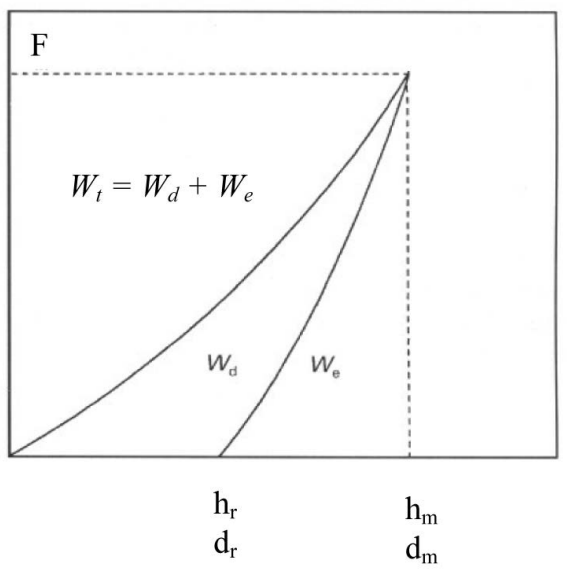

Fig. 2. Schematic relationship between the indentation depth/indentation diameter
and the load
2. ábra A terhelóerö és a benyomódási mélység/benyomódási átmérö sematikus
kapcsolata

The relationship between the value of $d_{r}$ (residual indentation diameter) and $h_{r}$ (residual indentation depth) can be written as:

$h_{r}=0,5 \cdot\left(D-\sqrt{D^{2}-d_{r}^{2}}\right)$

$d_{r}=\sqrt{D^{2}-\left(D-2 h_{r}\right)^{2}}$

The area under the loading curve of Fig. 2 accounts for the work that is introduced until the maximum penetration depth is reached. This work is called total indentation work:

$W_{t}=\int_{0}^{h_{m}} F_{1} \cdot d h$

Where $W_{t}$ the total indentation work,

$h_{m} \quad$ maximum indentation depth,

$F_{1} \quad$ the value of the load

during the loading phase.
The area under the unloading curve of Fig. 2 accounts for the amount of work that is recovered during unloading. This work is called elastic indentation work:

$W_{e}=\int_{h_{r}}^{h_{m}} F_{2} \cdot d h$

Where $W$ the elastic indentation work,

$h_{m} \quad$ maximum indentation depth,

$h_{r} \quad$ residual indentation depth,

$F_{2} \quad$ the value of the load during the unloading phase.

The difference between the two works gives the dissipated energy during the test:

$W_{d}=W_{t}-W_{e}$

After rearrangement the following expression can be given:

$\frac{W_{d}}{W_{t}}+\frac{W_{e}}{W_{t}}=1$

The depth sensing indentation (DSI) test is suitable for an energy based examination of the entire loading-unloading process.

\section{Materials selected for evaluation}

Main purpose of the experiments was to provide a wide range of porous solid building materials for an extended static indentation analysis in terms of both Brinell and DSI tests to be able to confirm or disconfirm the validity of earlier findings for concrete to further porous solid materials. The investigations covered elastic (clinker tile and clinker brick), elastic-plastic (compact limestone, high strength and normal strength concrete, polymer concrete, clay brick, rhyolite tuff) and plastic (sandlime brick, soft limestone, aerated concrete) materials, based on their stress-strain behaviour. Three metal samples (reinforcing steel, mild steel, aluminium) were also studied as control materials.

Both indentation tests were carried out by a $\mathrm{D}=10 \mathrm{~mm}$ diameter hard steel indenter. Maximum loads by the Brinell tests were taken in the range of $1.5 \mathrm{kN}$ to $30.0 \mathrm{kN}$ and for the DSI tests were taken in the range of $0.5 \mathrm{kN}$ to $30.0 \mathrm{kN}$. For comparison, rebound surface hardness measurements (Leeb- and Schmidt-type) were also carried out (results are not detailed in present paper). Compressive strength, Young's modulus, body density, apparent porosity and total porosity were also measured for all the materials tested.

\section{Results on mechanical properties}

Figs. 3 to 5 represent the uniaxial compressive strength, the Young's modulus and the theoretical sound propagation velocity of the examined materials as a function of the total porosity. The representation confirms the literature findings between mechanical properties and porosity that is usually given in power function form (as an example for the compressive strength as follows): 
$f_{c}=f_{c, o}(1-p)^{n}$

where $p$ is the total porosity, $f_{c}$ is the compressive strength, $f_{c .0}$ is the theoretical value of the compressive strength at zero porosity, and $n$ is a constant [6,7].The relationship can be written in an exponential form as well:

$f_{c}=f_{c, o} e^{-k p}$

where $k$ is a constant; further parameters of the formula are the same as above [8].

Results summarised in Figs. 3 to 5 demonstrate that the selection of the materials for present studies cover a wide range of performance, therefore, suitable for a general analysis.

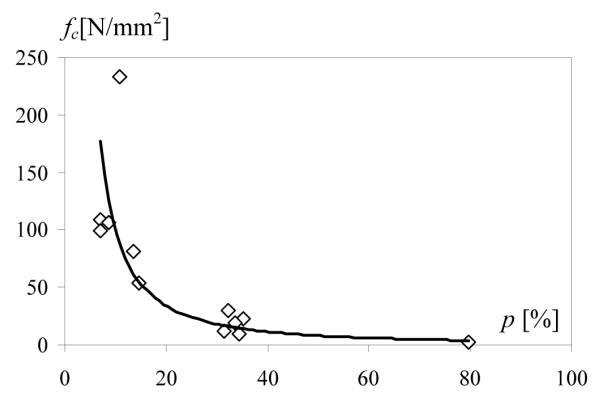

Fig. 3. Relationship of total porosity ( $p)$ and uniaxial compressive strength $\left(f_{c}\right)$ 3. ábra A teljes porozitás (p) és az egytengelyü nyomószilárdság $\left(f_{c}\right)$ kapcsolata

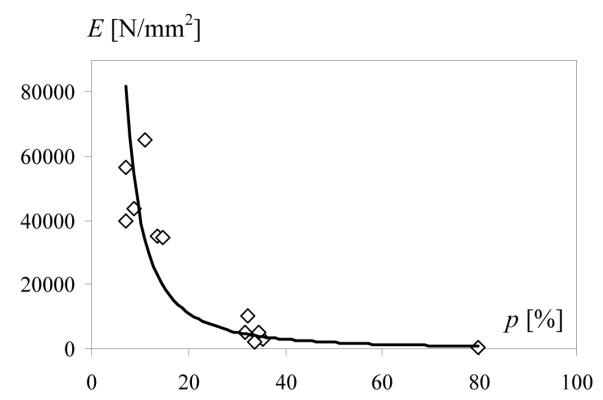

Fig. 4. Relationship of total porosity ( $p$ ) and Young's modulus (E) 4. ábra A teljes porozitás ( $p$ ) és a rugalmassági modulus (E) kapcsolata

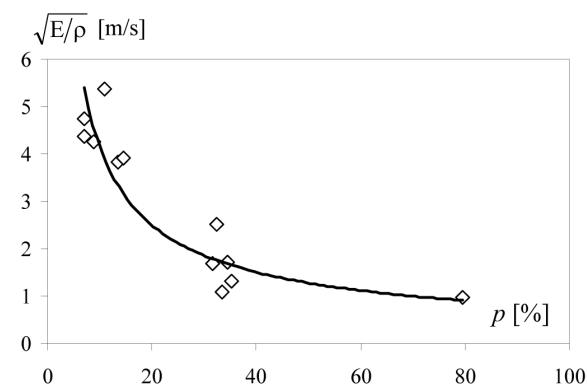

Fig. 5. Relationship of total porosity ( $p$ ) and sound propagation velocity () 5. ábra A teljes porozitás ( $p$ ) és a hang terjedési sebesség () kapcsolata

\section{The loading-unloading characteristics of the depth-sensing indentation test}

Experimental results indicated that the elastic, elasticplastic and plastic porous solid building materials can be distinguished easily by the indentation loading-unloading characteristics. Typical examples are shown in Figs. 6 to 9. One can clearly realize the differences between the total and elastic indentation works represented as areas under the specific loading-unloading curves.

For the clinker tile material one can observe that the deformations are mostly elastic and both the depths and diameters of the residual indentations are approximately one order of magnitude smaller than that of the maximum indentations. The loading-unloading curve has only a limited linear part; resulting the limited residual deformation.

In the case of the elastic-plastic materials one can generally observe that the dissipating (plastic) indentation energy and the elastic indentation energy have similar magnitudes, however, the ratios are very sensitive to the actual stiffness and strength of the material. Comparing the experimental results of the compact limestone (Fig. 7) and the rhyolite tuff (Fig. 8) it can be realized that the slopes of the unloading branches of the curves as well as the ratios of the maximum and residual indentation depths/diameters sensitively follow the differences in the stiffnesses and strengths of the two elastic-plastic materials.

The soft limestone sample was found to be almost completely plastic; the residual indentation depths/diameters are almost equal to that of corresponds to the maximum load. For the plastic solids one can realize the opposite behaviour in the ratios of indentation work than that was found for the elastic solids: the elastic indentation work accounts for an almost negligible part of the total indentation work.

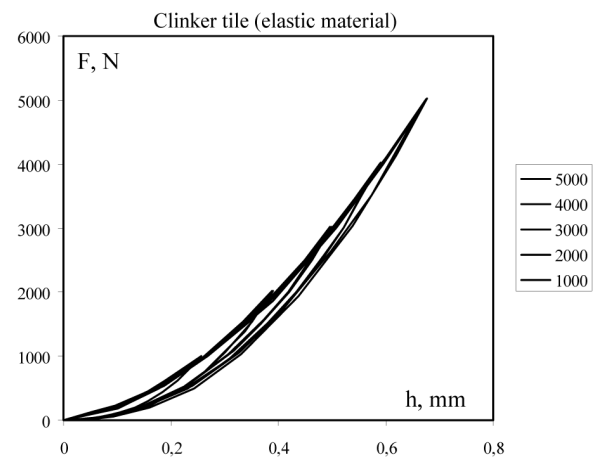

Fig. 6.a. Relationship between the indentation depth $(h)$ and load $(F)$ 6.a ábra A benyomódási mélység $(h)$ és a terhelöerö $(F)$ kapcsolata

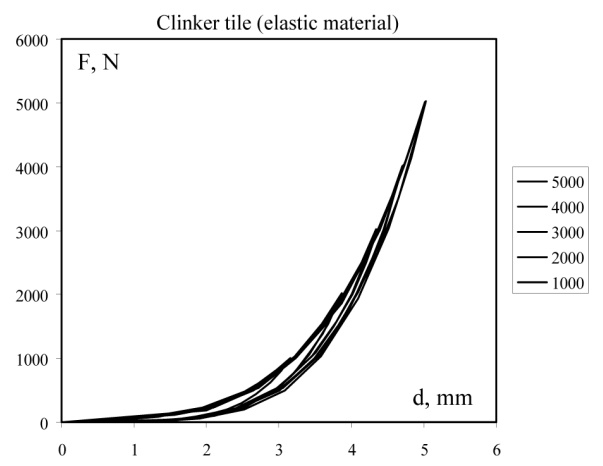

Fig. 6.b. Relationship between the indentation diameter (d) and load (F) 6.b ábra A benyomódási átmérő (d) és a terhelőerö (F) kapcsolata 


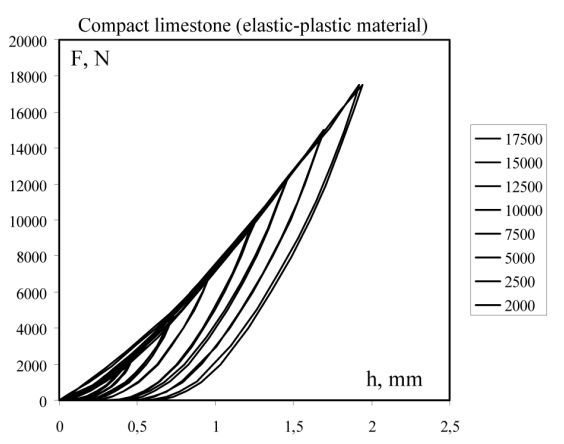

Fig. 7.a. Relationship between the indentation depth $(h)$ and load $(F)$

7.a ábra A benyomódási mélység $(h)$ és a terhelöerö $(F)$ kapcsolata

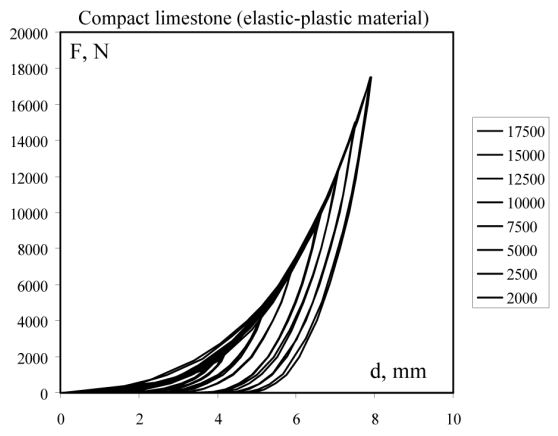

Fig. 7.b. Relationship between the indentation diameter (d) and load (F)

$7 . b$ ábra A benyomódási átmérö (d) és a terhelőerö (F) kapcsolata

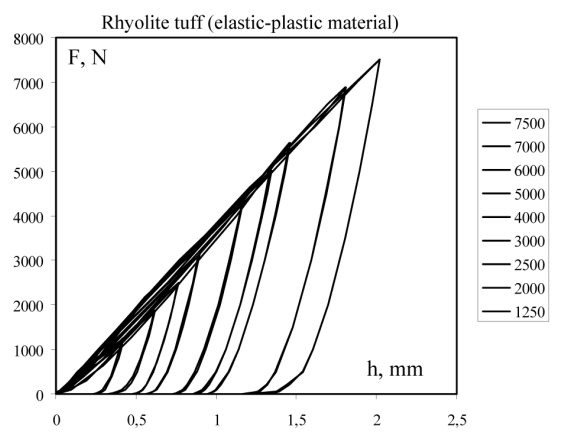

Fig. 8.a. Relationship between the indentation depth $(h)$ and load $(F)$

8. a ábra A benyomódási mélység ( $h$ ) és a terhelőerö (F) kapcsolata

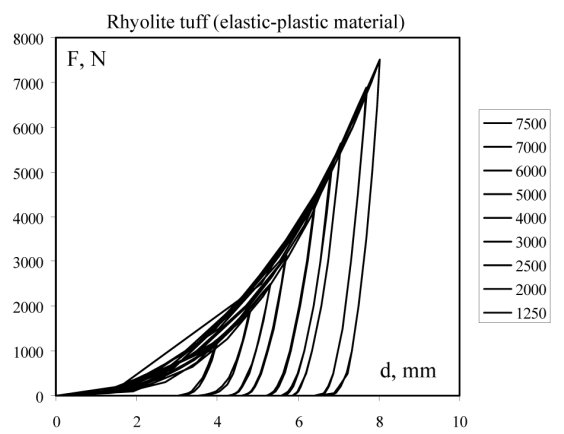

Fig. 8.b. Relationship between the indentation diameter (d) and load (F) $8 . b$ ábra A benyomódási átmérö (d) és a terhelöerö (F) kapcsolata

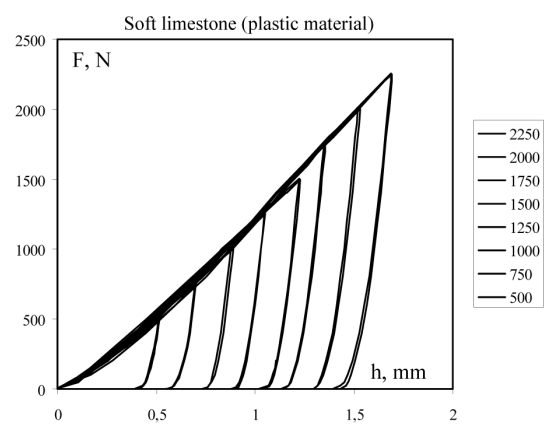

Fig. 9.a. Relationship between the indentation depth $(h)$ and load $(F)$ 9. a ábra A benyomódási mélység $(h)$ és a terhelöerö $(F)$ kapcsolata

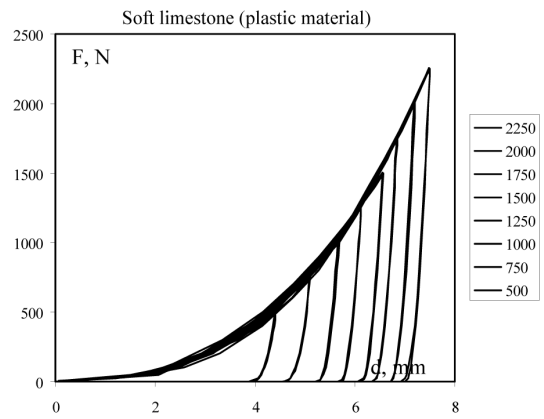

Fig. 9.b. Relationship between the indentation diameter (d) and load (F) $9 . b$ ábra A benyomódási átmérö $(d)$ és a terhelöerö $(F)$ kapcsolata

\section{Brinell hardness in the function of the load}

Figs. 10 to 13 indicate the calculated Brinell hardness results represented as a function of the testing load during the DSI tests. The two series of data correspond to the maximum and residual indentation diameters, respectively. It can be studied that apparent peak hardness values are showing on each response. The observed performance confirms the specific behaviour of porous solids noticed earlier for concrete under the ball indenter and indicates the existence of the mechanism of local densification and the formation of cone cracking [1]. At lower loads no full plastic response of the porous solids can be developed and the densification of the material under the ball indenter is not pronounced. Increasing load results increasing hardness values. At higher loads the local collapsing of the capillary walls in the porous solids and the local microcrushing of the material near the contact area results more pronounced densification; that can be realized in the apparent peak hardness when full plastic response is utilized.

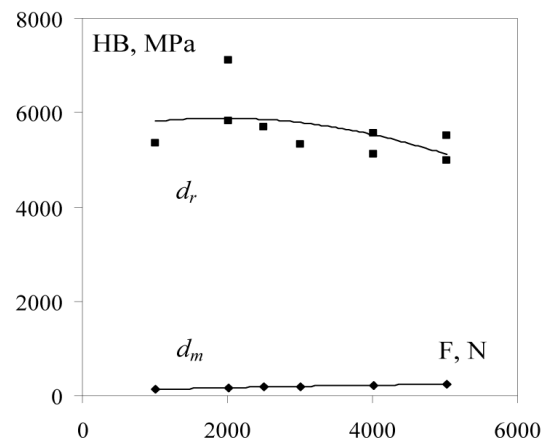

Fig. 10. Relationship between the Brinell-hardness and the load (clinker tile) 10. ábra A Brinell keménység és a terhelöerö kapcsolata (klinker burkolólap) 


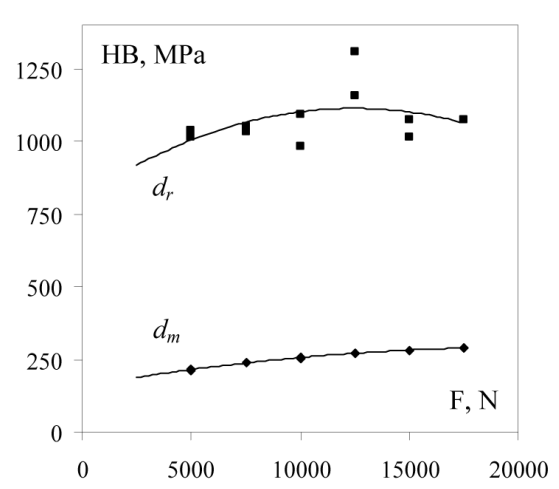

Fig. 11. Relationship between the Brinell-hardness and the load (compact limestone) 11. ábra A Brinell keménység és a terhelőerö kapcsolata (tömött mészkő)

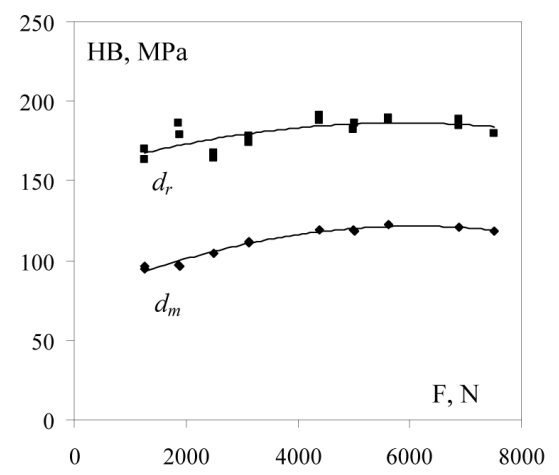

Fig. 12. Relationship between the Brinell-hardness and the load (ryolith tuff) 12. ábra A Brinell keménység és a terhelöerö kapcsolata (riolittufa)

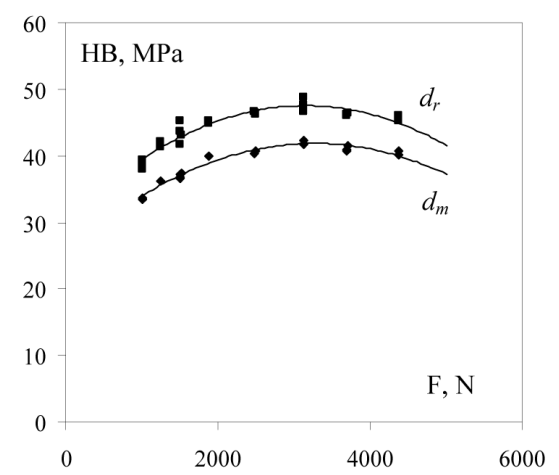

Fig. 13. Relationship between the Brinell-hardness and the load (soft limestone) 13. ábra A Brinell keménység és a terhelöerö kapcsolata (durva mészkö)

\section{Conclusions}

The hardness tests have been used for several centuries to determine the qualitative and quantitative characteristics of materials. The most suitable test method for scientific purposes is the indentation method to study the hardness of minerals, natural stones or artificial porous solid building materials. Present research utilized the Brinell macro hardness tests and the depth-sensing indentation (DSI) tests on 15 different types of porous solid building materials. The indention hardness tests were completed by the investigations of uniaxial compressive strength, Young's modulus, total porosity, apparent porosity, body density and rebound hardness tests. The laboratory experiments were aimed to analyze whether the experiences of previous investigations on concretes can be extended to further porous solid building materials. It was observed that the Brinell hardness tests and the DSI tests have almost equal outcome in respect of the load vs. residual indentation diameter $\left(F-d_{r}\right)$ response for identical testing loads (only slight differences are observable due to the slightly different load histories). The DSI test can reveal a relationship between the residual indentation diameter $\left(d_{r}\right)$ and the maximum indentation diameter $\left(d_{m}\right)$. The studies have shown that the earlier observations found for the Brinell hardness of concrete is correct and it can be extended to the tested porous solid building materials as well.

\section{References}

[1] Szilágyi, K. - Borosnyói, A. - Dobó, K.: Static indentation hardness testing of concrete: A long established method revived. Építőanyag, Volume 63, Issue 1-2, 2011, pp. 2-8.

[2] Meyer, E.: Untersuchungen uber Harteprufung und Harte. Zeitschrift des Vereines Deutscher Ingenieure, Vol. 52, No. 17, April 1908, pp. 645-654, 740-748, 835-844.

[3] Steinwede, K.: Über die Anwendung des Kugelhärteversuches zur Bestimmung der Festigkeit des Betons. DoctoralThesis, University of Hannover, Faculty of Civil Engineering. 20 Feb 1937, Gebrüder Jänecke, Hannover, 69 p.

[4] Gubicza J. - Juhász A. - Arató P. - Szommer P. - Tasnádi P. - Vörös G.: Elastic modulus determination from depth sensing indentation test. Journal of Materials Science Letters, Vol 15., 1996, Chapman\& Hall, pp. 2141 2144 .

[5] Sneddon, I. N.: The Relation between Load and Penetration in the Axisymmetric Boussinesq Problem for a Punch of Arbitrary Profile. International Journal of Engineering Science, Volume 3, Issue 1, May 1965, pp. 47-57.

[6] Mindess, S. - Young, J. F.: Concrete. Prentice-Hall, 1981, 671 p.

[7] Neville, A. M.: Properties of concrete. John Wiley\&Sons, 1996, 844 p.

[8] Mehta, P. K. - Monteiro, P. J. M.: Concrete: Microstructure, Properties, and Materials. McGraw Hill, 2006. 2006, 659 p.

$\underline{\text { Ref.: }}$

Katalin Szilágyi - Adorján Borosnyói - Zoltán Gyurkó: Static hardness testing of porous building materials. Építőanyag, 65. évf. 1. szám (2013), 6-10. p. http://dx.doi.org/10.14382/epitoanyag-jsbcm.2013.2

Porózus kőszerű építőanyagok statikus keménységvizsgálata

A keménységmérést évszázadok óta alkalmazza az anyagvizsgálat a kôszerú anyagok kvalitatív, illetve kvantitatív jellemzőinek meghatározására. Tudományos vagy anyagvizsgálati célra legalkalmasabbak a benyomódási keménységmérési vizsgálatok. A cikkben bemutatott kutatás során 15-féle porózus (természetes és mesterséges) kôszerú anyagon történt Brinell-féle makrokeménység vizsgálat és mélységérzékeny benyomódás (Depth Sensing Indentation, DSI) vizsgálat a teljes terhelési-tehermentesítési karakterisztika felvételével, eltérố terhelô erôkkel. A vizsgálatok során 10 mm átmérôjú, gömb alakú alaktestet használtak. A vizsgálatok igazolták, hogy a szakirodalomban fellelhetô megfigyelés, amely szerint a betonok Brinell keménysége függ a terhelốerố nagyságától, valamint, hogy létezik a Brinell keménységnek egy legnagyobb értéke, amely a terhelô erô vagy a benyomódás átmérôjének függvényében megadható, kiterjeszthetố valamennyi vizsgált porózus kôszerū anyagra. A vizsgálatok arra is rámutattak, hogy a porózus kôszerú anyagok mechanikai viselkedése markánsan elkülöníthetố egymástól a mélységérzékeny benyomódás vizsgálat terhelési-tehermentesítési karakterisztikái alapján rugalmas, rugalmas-képlékeny és képlékeny anyagokra.

Kulcsszavak: Brinell keménység, mélységérzékeny benyomódásvizsgálat, szilárdság, rugalmassági modulus, porózus szilárd anyag 